\title{
La medicina espiritual en Gregorio de Nisa como aporte para los retos de una Iglesia en salida
}

\author{
GABRIEL JARAMILLO* \\ Pontificia Universidad Javeriana (Colombia) \\ gabrieljaramillos@javeriana.edu.co \\ ORLANDO SOLANO** \\ Pontificia Universidad Javeriana (Colombia) \\ o.solano@javeriana.edu.co \\ ALEJANDRO NICOLA*** \\ Pontificia Universidad Católica de Chile (Chile) \\ alejandroenriquenicola@yahoo.com.ar
}

\section{Resumen}

En el presente artículo se abordará la medicina espiritual de San Gregorio de Nisa como un aporte para los retos de una Iglesia en salida. Para ello se partirá de una aproximación a la Iglesia en salida misionera, para luego abordar al Niseno y examinar en sus textos la importancia de la medicina en su reflexión especulativa, mística y pastoral, así como para la comprensión de su quehacer teológico como medicina espiritual. Finalmente, se recogerán algunos aportes para los desafíos de una Iglesia en salida.

Palabras clave: Teología, Patrística, medicina, Iglesia.

\section{Spiritual medicine in Gregory of Nyssa, contributions to the challenges of an outgoing church}

\begin{abstract}
This article will analyze the approach to the spiritual medicine of Saint Gregory of Nyssa, like. a contribution for the challenges of an outgoing Church. For this purpose, it will start with an approach to the Church in a missionary outing, to then approach Gregory's life and examined in his texts the importance of medicine and his speculative, mystical and pastoral reflection, as well as for the understanding of its theological work as spiritual medicine. Finally, some contributions will be collected for the challenges of an outgoing Church.
\end{abstract}

Keywords: Theology, Patristic, medicine, Church.

\footnotetext{
* Doctorando en Teología. Magíster en Humanidades y teólogo. Miembro del grupo de investigación Academia.

** Doctor en Teología, Pontificia Universidad Javeriana, Bogotá. Docente de tiempo completo de la Facultad de Teología de la misma universidad. Miembro del grupo de investigación Academia.

*** Doctorando en Teología. Magíster en Teología Patrística. Profesor de Teología, Historia de la Iglesia y Patrología en el Instituto Teológico de Córdoba (ITEC).
} 
INTRODUCCIÓN

El papa Francisco desde el inicio de su pontificado, ha planteado la necesidad de una "reforma de la Iglesia en salida misionera" (2013b: n. 17), que salga a curar heridas y a misericordiar a todos aquellos que se encuentran en las periferias existenciales. En dicha reforma, el Papa desea también "que la teología sea expresión de una Iglesia que es "hospital de campo', que vive su misión de salvación y curación en el mundo" (2015a: n. 4); además, quiere que el quehacer teológico aporte nuevos paradigmas y puentes de acercamiento con los nuevos contextos, para llevar medicina a los heridos en el campo de batalla.

Ciertamente, se trata de una renovación ya comenzada por el Vaticano II y plasmada en sus documentos (especialmente $G S, L G, A G, A C, A A$ ), así como en Evangelii Nuntidiandi y en diversos esfuerzos llevados a cabo por teólogos como Congar (2014) en Verdadera y falsa reforma en la Iglesia, así como Lonergan, De Lubac, Rahner y Suenens, en Teología de la renovación (1972). En el contexto latinoamericano se dan varios intentos de renovación recogidos por Saranyana (2005) y Berzosa (1994), teniendo como hito fundamental la Conferencia del Episcopado Latinoamericano celebrada en Medellín hace 50 años. Dicha Conferencia fue según Galli, "la única comunidad de iglesias a escala continental que hizo una recepción regional, colegial, y creativa del Concilio Vaticano II" $(2017,147)$.

El pontificado reformador de Francisco está haciendo realidad aquella percepción de Congar (2014), sobre las auténticas reformas que provienen de las periferias y está siendo motivo de reflexión para muchos teólogos, como se puede ver en las memorias del congreso La reforma y las reformas de la Iglesia (Spadaro \& Galli, 2016). La reforma de la Iglesia en salida que está impulsando Francisco, necesita ser reflexionada y abordada desde sus muchos aspectos, en ese doble dinamismo teológico ad fontes y a giorno (Galli, 2017), volviendo a las fuentes para responder a los problemas de hoy (Juan Pablo II, 1980; Congregación para la educación católica, 1989).

Piero Coda al ahondar en el pensamiento de Francisco en este doble dinamismo, afirma que "Agustín no es el único entre los Padres de la Iglesia que inspiran el magisterio de Francisco. Más allá de la referencia explícita, se trata de un estilo" (2017: 42), una manera de hacer teología que tiene raíces en otros Padres como San Basilio y San Gregorio de Nisa. En este trabajo, se pretende evidenciar las sintonías con Gregorio, en un aspecto muy afín al quehacer teológico como la medicina espiritual, entendida dentro del marco de la teología espiritual de Francisco como uno de los desafíos teológicos que tiene la Iglesia para poder vivir una verdadera reforma. 
Como lo expresa Rupnik: "cuando Francisco comienza a hablar de la 'Iglesia en salida', de la Iglesia de frontera, del 'hospital de campo' ... son todos mensajes importantes para decir que el Espíritu Santo pide a la Iglesia el coraje de ser sí misma" (2017: 27), abandonar estructuras imperiales y modelos que dividen la unidad en el Espíritu.

Lejos de ser una expresión espiritualista y piadosa, la medicina espiritual constituye un rico aporte del Evangelio, bellamente desarrollado por los Padres y que poco se conserva en la reflexión teológica occidental, que acentúo más, según Larchet, "la redención con categorías éticas y jurídicas” (2014: 267), por encima de la sanación del corazón. Cómo método investigativo se utilizó la hermenéutica de la apropiación de Ricouer, en la cual, el círculo hermenéutico se mueve entre la comprensión y la interpretación (2002), en orden a apropiar el mundo de los textos y las posibilidades de comprensión que abren al propio teólogo (Garavito, 2017).

Para el desarrollo de la exposición, se hará una aproximación a la Iglesia en salida (1); después, se abordará al Niseno y se examinará, en sus textos, la importancia del recurso medico en su reflexión especulativa, mística y pastoral (2); luego, se verá cómo su quehacer teológico se configura como medicina espiritual al estilo del Buen Samaritano (3), y, a modo de conclusión, se recogerán algunos aportes para los desafíos de una Iglesia en salida (4).

\section{LA REFORMA DE LA IGLESIA EN SALIDA}

En una célebre entrevista que concedió Francisco al inicio de su pontificado afirmó lo siguiente: "Yo sueño con una Iglesia madre y pastora ... como el Buen Samaritano que lava, limpia y consuela a su prójimo ... Las reformas organizativas y estructurales son secundarias ... La primera reforma debe ser la de las actitudes" (Francisco, 2013d). Estas palabras del Papa, buscan materializar su pensamiento con metáforas. El lenguaje de Francisco, así como el de los Padres, recurre a imágenes y símbolos para darle forma a sus intuiciones pastorales, como lo señala Brighenti (2015) en su apropiación del papa Francisco (19-39), la Iglesia debe dejar de ser aduanera, autorreferencial, narcisista, gnóstica, pelagiana, centralista, carrerista, clerical y encerrada, para pasar a ser madre, pastora, samaritana, pueblo, de puertas abiertas, de las periferias, como un hospital de campaña, una Iglesia accidentada por salir a tocar y abrazar la carne de Cristo.

Sin duda, el lenguaje metafórico le sirve al Papa para captar la realidad en su dinamismo, atesorarla en la oración y comunicarla en imágenes que faciliten el entendimiento. Al respecto, Tamayo (2000) plantea que la teología "explora metáforas alternativas, juega con imágenes nuevas, trenza 
nuevas ideas y crea nuevas perspectivas ... Una teología con estas características debe preguntarse por el modo más adecuado de hablar de Dios y prestar especial atención a las imágenes sobre Dios (16-17).

La reforma que quiere Francisco responde a esa actitud bautismal que está presente desde los Padres de la Iglesia, que veían la vida eclesial en un estado de conversión permanente: ecclesia semper reformanda (Kavanagh, 2014: 10). Este aspecto también tuvo una importancia decisiva en el Vaticano II, así como en las diferentes conferencias del Episcopado Latinoamericano, desde Medellín hasta Aparecida. Esta última habló claramente de la conversión pastoral, para pasar "de una pastoral de mera conservación a una pastoral misionera" (2007: 171).

Una Iglesia en salida hacia las periferias, desde el sentido metafórico usado por Francisco, es una comunidad de apóstoles que no teme ensuciarse, caerse y accidentarse; "prefiero mil veces una Iglesia accidentada . . . que una Iglesia enferma por encerrarse. Salid, ¡salid!” (2013a: n. 14). El mundo está herido y necesita ser curado, pero no con cualquier medicina. Francisco advierte que esta medicina implica renunciar a sí mismo, así como la cigarra que estalla por dar a luz, la Iglesia debe romper con su encierro y accidentarse, para poder "curar heridas y dar calor a los corazones de los fieles, cercanía, proximidad. Veo a la Iglesia como un hospital de campaña tras una batalla" (2013d) que sale a primerear a los heridos de muerte en el campo de batalla, que no teme ser herida con tal de curar con urgencia las dolencias físicas, psicológicas y espirituales.

\section{SAN GREGORIO DE NISA Y LA MEDICINA}

Ciertamente, el lenguaje metafórico que parte de la experiencia del pastor, que ora y reflexiona desde las periferias, no es propiedad exclusiva de Francisco. Esta forma de expresarse se puede encontrar en la vida de muchos misioneros, místicos y santos, como: San Ignacio de Loyola, San Alberto Hurtado, Santa Teresa de Jesús y San Gregorio de Nisa. En este último se encuentran muchas sintonías con la experiencia del papa argentino; su método teológico parte de ver la realidad con toda su crudeza, para juzgarla y transformarla. De este modo, hay citas textuales del Niseno que siguen siendo relevantes hoy, porque hay realidades del pecado que no cambian, a pesar de los siglos, como la realidad que describe en Pauperibus amandis (2001):

El tiempo actual abunda en desnudos y vagabundos. Una multitud de prisioneros de guerra llama a las puertas de cada uno de nosotros. No faltan extranjeros y exiliados. Por todos lados podemos ver manos extendidas que 
piden ayuda. El aire es de día su único techo. Su casa, los pórticos, los callejones, y las puertas desiertas de las plazas ... Viven una existencia vagabunda y salvaje, no por haberla elegido desde el principio, sino porque se la ha impuesto la necesidad y la miseria (67).

Antes de avanzar con los aportes del Niseno y las analogías que, proporcionadamente, se pueden establecer con el Papa, es necesario contextualizarlo, pues su pensamiento, así como el de Francisco, es autobiográfico. Ambos se implican en todo lo que dicen, y sus reflexiones brotan de las propias circunstancias existenciales, no de ideas abstractas. Para tal efecto, primero se hará una contextualización biográfica, para luego explicitar su estilo de hacer teología y su manera de usar el arte médico en la producción teológica.

\subsection{Contextualización biográfica}

El contexto de la Capadocia del siglo IV, bajo varios aspectos, parece ser tan complejo como el actual. Muchos tuvieron que derramar sangre en las persecuciones, hasta la promulgación de los edictos de Galerio del año 311 y el edicto de Constantino del año 313, en los cuales el cristianismo pasó a ser tolerado. Con el edicto de Tesalónica del año 380, el cristianismo se convirtió en la religión oficial del imperio y pudo gozar de cierta tranquilidad. Al mismo tiempo, la Iglesia enfrentó los desafíos de la inculturación con el mundo greco-romano y las tradiciones paganas que traían los nuevos miembros que se incorporaban por motivos sociopolíticos. A nivel eclesial, se celebró el Concilio de Nicea en el 325, donde se proclamó el símbolo de la fe; lamentablemente este no fue bien recibido por todos, y se generaron fuertes tensiones al interior de la Iglesia, entre los defensores de Nicea y los arrianos, eunomianos y demás corrientes que no se adherían a lo definido por dicho Concilio.

El siglo IV es considerado el siglo de oro patrístico, no porque brillara la paz y la armonía, sino porque, precisamente en esos momentos de crisis, surgieron héroes, columnas de la Iglesia y de la sociedad. Según San Juan Pablo II, los padres son "aquellos santos que, con la fuerza de la fe, con la profundidad y riqueza de sus enseñanzas, la engendraron y formaron en el transcurso de los primeros siglos" (1980, n. 1). Los Padres de la Iglesia jugaron un rol crucial en un delicado momento de síntesis cultural (Solano, 2015); hicieron teología en diálogo abierto con la cultura y profundizaron, con espíritu orante, en la Sagrada Escritura. Desde el fundamento bíblico, desarrollaron el dogma católico y respondieron de manera efectiva a los múltiples desafíos de la pobreza, el hambre, las injusticias sociales, el afán de la riqueza, la enfermedad y la discriminación social (González, 1988). 
Gregorio nació en el seno de una numerosa e influyente familia de Capadocia, alrededor del año 335 (Maraval, 2006: 190-191). Sus padres, Basilio y Emelia, provenían de ricas y prestantes familias cristianas que sufrieron muchas persecuciones a causa de su fe, por la cual estuvieron dispuestos, como los mártires de los primeros siglos, a perder su propia vida, emigrar de sus tierras y renunciar a sus riquezas. Su abuela Macrina recibió la fe por medio de San Gregorio Taumaturgo, quien a su vez era discípulo de Orígenes de Alejandría. Su abuela, al igual que su madre, Emelia, y sus hermanos Macrina, Basilio, Pedro y Naucracio; llevaron una vida de santidad dedica a la oración, al conocimiento de Dios y al servicio de los pobres (Silvas, 2007: 1-54).

\subsection{El estilo de hacer teología}

El estilo teológico del Niseno estuvo impregnado por el testimonio de vida y la formación que recibió en su familia, especialmente de sus hermanos Basilio y Macrina, quienes heredaron la tradición teológica-espiritual alejandrina, que tenía un respeto profundo por la cultura de cada época (Quasten, 1977: 283). Orígenes, fiel a su estilo, recomendaba tomar "de la filosofía griega las materias que pudieran ser como iniciaciones o propedéutica para el cristianismo" (1969: 186-189).

La formación cristiana tenía como meta el conocimiento de la Escritura; pero, para ello, era preciso pasar primero por el conocimiento de la retórica y las demás ciencias. Lo anterior incluye, en palabras del propio Taumaturgo (1994), "la lección sublime, divina y la más deseada por todos, que enseña la fisiología" (132-133) y la medicina que, según el Niseno, "es cosa apreciada entre los hombres" (195: 103; 2014b: 345). La estima por la medicina y su relevancia dentro del quehacer teológico-pastoral está presente en Emelia, la madre de Gregorio, que le aconseja a Macrina los "cuidados médicos, ya que también este arte ha sido dado por Dios para la salud de los hombres" (Gregorio, 1995: 103). Basilio, por su parte, fue el "fundador de la primera 'Ciudad hospital' del mundo" (Janini, 1946: 4), y su hermano Naucracio "cuidaba con sus propias manos a algunos ancianos que vivían en la pobreza y en la enfermedad, estimando que era coherente con su estilo de vida tomar sobre sí esta ocupación" (Gregorio, 1995: 59).

Para el Niseno, era imposible concebir un seguimiento de Cristo sin una opción integral por amar al prójimo, al estilo del Buen Samaritano (Lc 10, 25-37). Es así como sus elevados desarrollos teológicos no se quedan en el escritorio (Francisco, 2015a), sino que se hacen vida, al cargar sobre sí los problemas de los más pobres, de aquellos que no tenían acceso a muchas posibilidades materiales y humanas, dentro de las cuales estaba el 
recurso a los conocimientos científicos y médicos. Desde su preocupación misionera, Gregorio decidió ahondar en su formación, para responder a los desafíos de quienes estaban en la periferia: "porque si alguno buscase que la Iglesia fuese su maestra en todas estas cuestiones (médicas), porque no tenga necesidad de oír ninguna voz extraña ... disertaré yo en este tratado acerca de ellas" (2016: 53).

\subsection{El rol de la medicina en su vida y sus escritos}

Como lo atestiguan sus escritos, el obispo de Nisa fue capaz de incorporar a su quehacer teológico los mejores aportes de la medicina, para el único fin de la "inteligencia del cristianismo" (Orígenes, 1969: 186). Dada la amplia bibliografía que se puede encontrar sobre el uso de la medicina en el Niseno, para el interés de este escrito se agrupará de dos maneras: como medicina pastoral y como medicina espiritual. Dejando esta última para el siguiente punto, se ahondará aquí sobre la medicina pastoral, entendida, según Niedermeyer, como la "zona limítrofe entre la medicina y la teología" (1955: 37). Esta forma de medicina, contempla a la persona como un todo, en el que lo físico se relaciona con lo ético y lo espiritual, y viceversa, pero guardando la especificidad de cada disciplina. Como afirma Monge, "lo específico de la medicina es el 'arte de curar' y aquí nos interesa la 'cura' en otro sentido: lo que se denomina 'cura de almas"' (2003: 29).

Según Janini (1946), Gregorio no sólo se fundamenta rigurosamente en los conocimientos de su época, como "el de usu partium del médico de Pérgamo ... (y) el de Hipocratis et Platonis dogmatibus" (30); además, se apoya en los testimonios de diferentes médicos: "escuché una vez a un experto del arte médico hablar con la debida competencia" (86). Gregorio dialogaba con ellos sobre temas de complejo discernimiento, con el fin de construir "sobre el fundamento científico de la medicina, no sólo muchas de sus teorías antropológicas, sino aún la misma terapéutica del espíritu y el ejercicio y la práctica de algunas virtudes cristianas" (1946, xviii-xix). Es así como, para Janini, Gregorio se convierte en el "fundador de la medicina pastoral" (157).

La estrella de Nisa logra una bella síntesis entre medicina y teología, que, en cierto modo, es tributaria de la paideia griega, la cual buscaba, según Jaeger, "la unidad inseparable de la paideia, no como la educación del cuerpo y del espíritu por separado ... produciendo no una estridente disonancia, sino una bella armonía" (2001, 228-229), como las cuerdas de una lira bien interpretada. La educación, para los griegos, no era un ejerci- 
cio enciclopédico, sino una experiencia espiritual-existencial, que involucraba la integridad de la persona: "el alma sana y el cuerpo sano" (Jaeger, 2001: 285).

De este modo, Sócrates se entendía como un cura de almas (Platón, 2014, 30b), "como un médico cuyo paciente fuese no el hombre físico, sino el hombre interior" (Jaeger, 2001: 50); un maestro que buscaba la salud en la virtud, entendida como el equilibrio o término medio entre el exceso y el defecto. Aristóteles, por su parte, entendía el arte de la medicina como un discernimiento, el cual le servía de metáfora para hablar de la ética y del desafío que esta tiene al aplicar leyes universales a pacientes particulares:

Y si tal condición tiene la teoría ética en general, con mayor razón aún toda proposición sobre casos particulares carece de exactitud, como quiera que semejantes casos no caen bajo de alguna norma técnica ni de alguna tradición profesional. Menester es que quienes han de actuar atiendan siempre a la oportunidad del momento, como se hace en la medicina y el pilotaje (2012, II, 2).

En su primera obra, De Virginitate, Gregorio (2000) se valió de la medicina para mostrar cómo el celibato, en lugar de debilitar humanamente, enriquece con "la fuerza y la salud, no por el ejercicio corporal" (146), sino por el cultivo de la virtud y de una vida saludable (150) que concede un corazón indiviso. Consciente de los múltiples desafíos de su época, el Niseno usó la medicina para proponer una concepción antropológica más acorde con el dato revelado, como se puede ver en De Hominis Opificio, en donde dialoga "con ideas aristotélicas y platónicas y con la filosofía teleológica" (Janini, 1946: 52), para desarrollar más profundamente el dogma bíblico sobre la creación (Gn 1, 26-27).

La grandeza humana radicaba, para los griegos, en ser un microcosmos; pero es ampliada, en el cristianismo, por la concepción del ser humano como imagen de Dios. Gregorio (2016), aporta a esta reflexión, considerando a la persona como una armonía tripartita compuesta por "el cerebro, el corazón y el hígado" (53), hasta llegar a cada uno de los órganos, que también expresan la huella divina y "hacen su contribución necesaria para el todo" (53). Ante el dualismo griego, que afirmaba la preexistencia del alma, Gregorio sostiene la importancia del cuerpo, que es creado junto con el alma. De igual manera, defiende la existencia de un ser animado, que es imagen de Dios desde el primer momento de la concepción, ante aquellos que sostenían la animación tardía del embrión. Para el Niseno, "la forma del futuro hombre está ahí potencialmente, pero está oculto porque no es posible de ser visto antes de su necesario desarrollo" (50). 


\section{LA MEDICINA ESPIRITUAL EN GREGORIO DE NISA}

En Gregorio, se puede ver plasmado el método de aproximación de la realidad que más adelante incorporará la teología latinoamericana. Su reflexión teológica parte del encuentro con un hecho concreto: los leprosos, los pobres, los prestamistas usureros, los esclavos o alguna dama con un pedido especial para crecer en la virtud. Gregorio juzga y discierne cada necesidad concreta a la luz del Evangelio, interpretando exegéticamente el texto y valiéndose de múltiples metáforas y alegorías, que le permiten apropiar el mensaje, para que este finalmente pueda tener un impacto transformador en la realidad.

Vale la pena detenerse en la exégesis del Niseno, donde incorpora la tradición antioquena y su preferencia por el sentido literal del texto, así como la tradición alejandrina, que promueve el recurso al sentido alegórico-espiritual, si las circunstancias lo requieren, por medio de "la $\alpha \kappa o \lambda o v \theta l \alpha$ : la concatenación natural de los significados y de los hechos históricos, los cuales encierran un valor espiritual más profundo" (Moreschini, 2014: 110). Aquí, la alegoría le permite a Gregorio, según Drobner, dar "el paso de lo que es corporal a aquello que es espiritual" (2006: 65), como ya lo había hecho Orígenes de Alejandría. Según Fernández (1999), este último tomó "los tres elementos de la medicina griega, señalados por la afirmación hipocrática: ... la enfermedad, el enfermo y el médico” (12), para argumentar cómo Cristo es el médico que viene a sanar el alma enferma por el pecado.

En el Niseno y su quehacer teológico, el verbo encarnado es el médico (2015b: 255) que, en su economía salvífica-medicinal, sale a curar la herida a la humanidad (2012: 44), a través de un proceso gradual y pedagógico, que tiene como centro la misericordia divina y como fin la restauración de la imagen o huella original que se empañó por culpa del pecado. En este sentido, la economía de la salvación se puede entender como medicina reconstitutiva de la imagen, como lo explica Moreschini (2014):

Tarea de la economía divina será, en este momento, la restauración de la imagen. La encarnación del Hijo de Dios es la condición indispensable para que ella se dé; mientras tanto, veremos cómo puede el cristiano, siguiendo el ejemplo instituido por Cristo, iniciar ya en esta vida la reconstitución de la felicidad, y, sobre todo, de la dignidad originaria, gracias al esfuerzo del alma, que tiende hacia el bien (40).

Para desarrollar la medicina espiritual en Gregorio como aporte para una Iglesia en salida, se abordarán cuatro puntos: 1) Cristo médico, 2) el quehacer teológico como medicina espiritual, 3) la medicina espiritual 
como pedagogía, 4) la medicina de la misericordia, y 5) al estilo del Buen Samaritano.

\subsection{Cristo médico}

Las Sagradas Escrituras dan cuenta de la alegoría de Dios como médico, el pueblo o el pecador los enfermos, y del pecado y sus múltiples consecuencias como enfermedad. Ni Francisco ni Gregorio se han inventado algo nuevo; su opción por el lenguaje metafórico-médico es por fidelidad a la Escritura y por sensibilidad con la realidad. Es claro cómo Dios, siendo comunión de amor, en un acto de salida amorosa de si, crea al hombre y a la mujer $(\mathrm{Gn} 1,27)$ para que amen; pero, al desobedecer, se produjo una herida mortal $(\mathrm{Gn} 2,17)$ que rompe con la belleza y armonía original de la creación.

Dios no se cansa de buscar a su creatura y salir a su encuentro, conformando un pueblo con Abraham y dándole en la ley de Moisés una medicina "que cura todas tus dolencias" (Sal 102, 3). Sin embargo, esto será tan sólo una prefiguración del siervo sufriente, que vendrá a cargar con las enfermedades de la humanidad y a curarla con sus propias heridas (Is 53, $5)$.

En los Padres de la Iglesia, se puede encontrar una percepción más genuina del hebreo Yéchua - Jesús_-, que quiere decir Yavhé salva, y que proviene de yasha, que significa salvar y corresponde al término neotestamentario $\sigma \omega \tau \eta \rho i \alpha$ : salvación, más específicamente, liberación y salvación al mismo tiempo. La misión de Cristo era comprendida por los Padres como salvación y curación. Para Brouchet (1968), dentro de las imágenes de Cristo que usa Gregorio: la luz, el liberador, el reformador, el redentor, entre otras (643), ninguna figura es tan relevante como la del médico para hablar de la misión de Cristo. Así se reconoce, "en el uso privilegiado de este término, la influencia de una cierta visión de la economía, de la parábola del Buen Samaritano, de los textos origenianos y finalmente del gusto de nuestro autor por todo lo que toca a la medicina" (642).

Cristo mismo quiere presentar su obra salvífica como una medicina; Él viene a "dar la vista a los ciegos" (Lc 4,18$)$ y a ofrecer la curación de cualquier tipo de dolencias a cuantos se acercan a tocarlo (Mc 3, 10). Para Gregorio, Cristo es el médico que vino a curar a la humanidad enferma (Mt 9,12) de esas tres consecuencias del pecado que recoge Moreschini en la obra de Gregorio. Estas consisten en: haber dado origen al mal, haber dejado al hombre en el elemento material, y, "en tercer lugar (y esta fue la consecuencia más grave), la destrucción de la imagen de Dios, que el hombre representaba en su naturaleza apenas salida de la mano del creador" 
(Moreschini, 2014: 29-30). Para el obispo de Nisa, el Verbo, al hacerse carne, asumió la condición humana para curarla:

Nuestra naturaleza, enferma, tenía necesidad del médico; el hombre, caído, necesitaba de alguien que lo levantara; el que estaba sin vida necesitaba del que da la vida; el que había resbalado fuera de la participación del bien necesitaba de quien lo devolviera al bien; el preso en la oscuridad anhelaba la presencia de la luz; el cautivo buscaba al redentor, el presidiario al defensor, el subyugado en la esclavitud al libertador (1990: 77).

Para los Padres de la Iglesia, según Larchet, la expresión, "lo que no hubiera sido asumido, no habría podido ser curado, se aplica no solo a la naturaleza humana hipostasiada por Cristo en su totalidad, cuerpo, alma y espíritu, sino también a esta naturaleza caída que Cristo, por esta razón, se ha dignado revestir igualmente" (2014: 264). Cristo, por su obediencia, nos curó del pecado original de la desobediencia, y nos dejó la medicina espiritual con la que podemos curarnos y curar en Cristo. Janini explica que esto se puede lograr mediante "un procedimiento terapéutico análogo al que usa la medicina en las enfermedades del cuerpo ... El médico del alma deberá, pues, estudiar la causa del pathos y combatir directamente el elemento responsable del desorden" (1946: 73).

\subsection{El quehacer teológico como medicina espiritual}

Al considerar a Cristo como médico del espíritu, el teólogo que reflexiona sobre la revelación del Logos en la historia, se hace partícipe de su misión y desea salir en busca de todos "los que necesitan médico" (Mc 2, 17). Es así como los teólogos se convierten en curas de almas, en sanadores que ya se encontraron con el médico y están siendo sanados de sus propias enfermedades, para no recibir el reproche que le hicieron injustamente al Señor: "médico, cúrate a ti mismo" (Lc 4, 23). De esta forma, la labor teológica también exige un esfuerzo continuo por seguir a Cristo a través de la oración, el trabajo especulativo y la práctica de la misericordia con el prójimo, porque los buenos teólogos, según Francisco, "con su reflexión, derraman ungüento y vino en las heridas de los hombres" (2015a).

En las obras del Niseno, se puede apreciar una constante preocupación por hacer de la teología una medicina espiritual. Como aparece en el prefacio de su obra más sistemática, extensa y filosófica, el Contra Eunomio, la teología, así como la medicina, exige un trabajo de discernimiento, para no derramar la medicina teológica en un paciente que no esté dispuesto a recibirla y termine pasando que la cura sea peor que la misma enfermedad. La teología, como afirma la Comisión Teológica Internacional, implica de 
suyo una "disposición a buscar la forma en que el Espíritu de Dios pudiera estar hablando por medio de tales acontecimientos" (2011: 15), de manera que la medicina conceda salud y no muerte, como lo afirma Gregorio (2014b):

Viendo que la perdida gratuita de muchas drogas preparadas para enfermosincurables no produce resultados significativos en sus cuidados, así como en el sentido de ganancia para el receptor o reputación para el bienintencionado benefactor. Mas bien, estos intentos se vuelven en muchos casos la ocasión de un cambio para lo peor. Los desesperanzados enfermos, y ahora pacientes que mueren, reciben solo un apresurado final de medicinas más activas. $(\mathrm{I}, 1)$

En medio de su exposición sistemática y doctrinal, Gregorio no pierde ocasión para usar la metáfora médica como instrumento de comprensión de la obra de Cristo, porque "la forma más adecuada para hablar de Dios es la simbólica" (Tamayo, 2003: 20). De este modo, Gregorio leyó la economía de la salvación en clave médica, debido a que "decimos que Él nació entre nosotros para la cura de la enfermedad del pecado, adaptando el ejercicio de su poder sanador en una manera correspondiente al sufrimiento" (2014b, III, IV, 65).

La medicina espiritual implica que el teólogo sepa hacer teología de rodillas, desde una experiencia de oración; para Gregorio, la teología es un quehacer que "de altura en altura va subiendo a las cosas sublimes, elevándose siempre por encima de sí mismo ... (hasta llegar al) santuario oculto e invisible del conocimiento de Dios" (2015b: 253). La teología para el Niseno es espiritual (Mateo-Seco, 2006: 843-853), de contemplación apofática de la belleza del misterio de Dios y del propio ser humano que está por develarse.

Esta belleza salvará al mundo, en cuanto mueve a una reverente contemplación de la verdad que está oculta en el pobre y el que sufre, como íconos de la presencia de Dios. De esta manera, la teología, como ascenso hacia la belleza de Dios, implica un proceso espiritual, en el que primero es preciso pasar por la purificación del fuego del amor. Según el Niseno, "no debemos envalentonarnos y escalar la montaña espiritual sin haber lavado previamente los vestidos de nuestro corazón y haber purificado el alma derramando sobre ella pensamientos apropiados" (2015a: 17). La dinámica medicinal que busca restablecer la belleza original perdida por el pecado, implica que el teólogo esté inmerso en la terapéutica de la oración, que consiste según Francisco en "animarse a pensar rezando y rezar pensando" (2015b). 
En este sentido, Gregorio en la homilía cuarta De Oratione Dominica, interpreta la oración del Padrenuestro como curación para la enfermedad de la palabrería, en la que también caen los teólogos cuando no unen el corazón con los labios. De este modo, si se pide hágase tu voluntad así en la tierra como en el cielo, se espera que el corazón quiera donarse con obediencia a Dios, porque: "la salud del alma es que la voluntad divina encuentre un camino fácil en nosotros" (1983: 86).

En su reflexión, el Niseno recoge el estudio de un médico que, al identificar la causa de la enfermedad en la desviación de uno de los órganos, proponía que "el retorno al estado primitivo y natural de los elementos trastornados por el mal era la terapia que podía curar el morbo de raíz" (1983: 86). En este sentido, la enfermedad del pecado es una desviación que separa a la persona del querer de Dios y requiere una terapia en la que Cristo vaya sanando el corazón por medio de los pensamientos que surgen de la oración. Gregorio propone "una terapia para la enfermedad que se ha infiltrado en el alma" (1983: 88), un proceso paciente de sanación, porque la persona "no retorna al bien con la misma facilidad con la cual se ha vuelto al mal: se puede observar un análogo decurso también por la vida física; un organismo enfermo no sana en el mismo modo ni con la misma rapidez con la cual un organismo sano se enferma" (89).

\subsection{La medicina espiritual como pedagogía}

El estilo de hacer teología de Gregorio (2015b) es un proceso pedagógico de ascenso hacia el médico, que va sanando conforme se va subiendo hacia Él, por medio de un proceso que implica un "nacimiento continuo" (219). Es un quehacer en continuo $\varepsilon \pi \varepsilon \kappa \tau \alpha \sigma l \varsigma$ o progreso (Solano Pinzón, 2018) hacia la contemplación de Dios, en el que se va recuperando la belleza originaria, a través de un itinerario pedagógico y adecuado a cada persona. Como afirma Gregorio, "un adolescente no trabaja como un adulto, ni tampoco consiente en ir de la mano de una niñera. Cada época de la vida tiene sus propiedades y características" (13) y requiere de la sabiduría de los teólogos, que "proponen primeramente a sus oyentes los elementos de la doctrina, y luego poco a poco los introducen en los conocimientos más perfectos y en los misterios" (1988: 65).

Se trata de un crecimiento pedagógico en la virtud o $\alpha \rho \varepsilon \tau \varepsilon ́$, entendida como el término medio o equilibrio entre el exceso o el defecto. La salud, así, se entiende en Gregorio como el equilibrio adecuado en el que se evita ir "de uno a otro extremo" $(1988,82)$, a la luz de un serio discernimiento en el Espíritu, que sopla en cada circunstancia lo que conviene, como "lo hacen los médicos: a unos los ponen a dieta, a otros hacen comer más, 
para que o con el ayuno o con el alimento unos y otros se pongan sanos" (67).

En De Virginitate, Gregorio expresa estas mismas ideas aplicadas a la virtud de la virginidad. Es interesante cómo la analogía médica le permite hacer un discernimiento más agudo de los medios ascéticos que se escogen para crecer en la virtud. La enfermedad o la salud del espíritu se aprende a distinguir gracias a la experiencia y a un buen tutor o consejero espiritual, que ayude a discernir según las circunstancias. El Niseno lo expresa de esta manera:

El mal ha sobrevenido por una excesiva insuficiencia o por una desmedida hartura: en ambos casos, la falta de moderación ha conducido al mismo término. En consecuencia, quien se cuida de la vida y de la salud del alma se mantendrá a sí mismo en el equilibrio (2000: 158).

Mikoski (2006), al hablar de la relación entre Bautismo, Trinidad y pedagogía eclesial en Gregorio, plantea la necesidad de no separar el dogma de su realidad existencial y práctica, pues forman un todo diferenciado que aporta un camino pedagógico para el creyente, "separar uno del otro sería distorsionar a Gregorio" (175). Desde el Bautismo, comienza un "proceso de crecimiento y ascenso; incluso en el punto de moverse más allá del discurso racional, este proceso es inherentemente pedagógico, en cuanto que requiere esfuerzo, guía, transformación del carácter y progreso hacia el objeto de nuestro deseo" (181). El quehacer teológico del Niseno es eminentemente pedagógico y vigente para una Iglesia en salida misionera, porque como continúa explicando Mikoski, se puede comprender el:

[...] contenido doctrinal o el currículo de esta divina enseñanza ... como una terapia cognitiva para la persona enferma de muerte. El 'núcleo del currículo', no estaba dirigido principalmente a una especulativa curiosidad intelectual. Apuntaba a curar la persona enferma y ayudar a él o a ella a florecer en la maravilla doxológica (175).

\subsection{La medicina de la misericordia}

La oración, la reflexión sistemático-doctrinal, la conversión y el crecimiento en la virtud, si no están acompañados de misericordia, están vacíos. La teología debe estar siempre volcada hacia la vivencia de la misericordia con los que más sufren, porque, como afirma Gregorio, un teólogo sin misericordia se parece a un "médico que mate, y que de médico lleva sólo el nombre y la apariencia” (1988: 82.). El mundo muere por falta de misericordia y la teología no puede ser indiferente a las dinámicas del mercado 
y las finanzas, que hacen a unos más pobres y a otros más ricos, a través de préstamos internacionales. Así, como Gregorio (1988), los teólogos deben denunciar "los gérmenes pestíferos de los préstamos" (75) usureros, porque quien presta a un interés muy elevado padece "la enfermedad de la avaricia, se hizo duro y sórdido para consigo mismo y para con los suyos" (81).

No puede existir sintonía más grande entre Gregorio y Francisco que la consideración de la necesidad de curar con la misericordia o misericordina, como se le llamó a la Coronilla de la Misericordia que se regalaba en una cajita de pastillas, durante el Jubileo de la Misericordia. Para Francisco, la Iglesia en salida debe ser una Iglesia de Misericordia, en la que la verdad más importante sea la de un Dios que se hace pecado por los hombres y mujeres de este tiempo, no para juzgarlos, sino para abrazarlos con su misericordia, para escogerlos con esa mirada de misericordia que retrata $\mathrm{Ca}$ ravaggio en su cuadro sobre el llamado de Mateo, para curarlos como el Buen Samaritano y mandarlos a ser misioneros de la misericordia.

A lo largo de sus obras, el Obispo de Nisa ofrece la medicina de su quehacer teológico para sanar "el resto de las enfermedades del alma, la envidia, el rencor, el odio, y cualquier otra cosa" (2000: 64). Gregorio no se contenta con denunciar la corrupción y el egoísmo, sino que, al mismo tiempo, propone un discernimiento evangélico que cure dichas enfermedades:

Sé misericordioso con tus hermanos que sufren calamidades. Lo que no le das a tu estómago, dáselo a los hambrientos ... Por estas palabras tiernas y humanas, ayuda con tus bienes a resolver la miseria. Que la multitud de pobres y enfermos encuentre un refugio en ti (64).

En Pauperibus amandis, el Niseno analiza la enfermedad de la lepra y sus consecuencias sociales en aquellos que la padecen. Los leprosos tenían un trato peor al de los animales, al ser rechazados por sus propios familiares y amigos; en lugar de ser sujetos de misericordia y vivencia de la caridad, "su espantosa enfermedad los ha convertido en bestias" (2001: 201). Movido por su celo pastoral, Gregorio contradice las tesis sobre el contagio de la lepra por el trato con los enfermos o por el aire (Holman, 2001: 158), y recoge el testimonio de personas que "dedicaron su vida a los enfermos desde su juventud hasta su ancianidad ... (porque) es sólo en el interior donde se desarrolla la enfermedad, invadiendo la sangre por humores podridos que la infectan" (Gregorio, 2001: 205).

Como buen seguidor de Jesús, la misma enfermedad de la lepra le servía de pretexto para suscitar la fe de sus fieles, porque "no sólo conocía, según la medicina científica, el arte de curar los cuerpos, sino que, además, 
lo propone también para las enfermedades del alma" (Janini, 1946: 72). De este modo, al promover la solidaridad con los leprosos, desde el Evangelio y los conocimientos médicos, se vale de la enfermedad de la lepra y el peligro de contagio como "metáfora espiritual" (Holman, 2001: 144), para hablar de enfermedades más profundas que sufren aquellos que, teniendo la piel sana, necesitan de un "contagio inverso ... las personas que los asisten pueden recibir curación para sus propias 'enfermedades' de riqueza y orgullo. En este sentido, la Iglesia necesita del contacto con leprosos en orden a curar enfermedades espirituales" (Holman, 2001: 162). En palabras de Francisco, la Iglesia necesita tocar la carne de Cristo en aquellos que sufren y abrazarlos como el santo de Asís, para ser curados de la enfermedad de su encierro y narcisismo.

En esta segunda homilía, sobre el amor a los pobres, Gregorio relaciona con fineza dos pasajes evangélicos que lo inspiraban mucho en su quehacer teológico: el juicio final en Mateo 25, 31-46, que enumera las obras de misericordia y el Buen Samaritano en Lucas 10, 25-37. Gregorio, al igual que Francisco, veía en estos dos pasajes el modelo de un nuevo estilo de santidad cristiana, a semejanza de Cristo, que se hizo Buen Samaritano de la humanidad. Las obras de misericordia con los hermanos que están al borde del camino deben llevar a configurar una Iglesia samaritana y un quehacer teológico que vea a Cristo en el sufrimiento del inocente (Gutiérrez, 1995). Arrodillarse ante la pobreza y sinsentido de tantos, para primerear y misericordiar, discerniendo los mejores caminos que hagan la caridad afectiva mucho más efectiva. ¿Qué debemos hacer? (Lc 10, 25) es la pregunta fundamental que extrae Gregorio de estos dos textos:

¿Qué debemos hacer? No romper la unidad del Espíritu, es decir, no considerar como extraños a aquellos seres que participan de nuestra naturaleza; no imitar a los hombres que condena el Evangelio. Estoy hablando del sacerdote y el levita que pasó por el camino sin la menor compasión por el hombre desafortunado a quien los ladrones habían dejado medio muerto ... ¿Cómo seremos inocentes (nosotros) si imitamos a estos culpables? Y, de hecho, el hombre que había sido atacado por bandidos, presenta una escena similar a aquellos que estos días están atrapados en el sufrimiento (2001: 202).

\subsection{Al estilo del Buen Samaritano}

Francisco sueña con una Iglesia Samaritana que primeree, se involucre, acompañe, fructifique y festeje (2013b: 24). La urgencia del quehacer teológico en este hospital de campo es clara, y exige de quienes lo realizan, como en el caso del Obispo de Nisa, una mejor formación interdisciplinar 
en medicina y en las demás ciencias, así como un discernimiento cada día más profundo, que permita interpretar la Escritura para sanar los corazones heridos. De esta forma, una Iglesia Samaritana no es otra cosa que la continuación de esa eclesiología de sanación que quiso impulsar la renovación conciliar, como quedó plasmado en las palabras de Pablo VI "la antigua historia del samaritano ha sido la pauta de la espiritualidad del Concilio" (1965).

Cabe agregar que esta debería seguir siendo la pauta de la Iglesia, en su proyección y actualización en los diferentes contextos, especialmente en aquellos donde es más palpable la pobreza y el sufrimiento. Con la inspiración que aporta el quehacer teológico-medicinal del Niseno, es importante preguntarse: ¿Cuántos hermanos no están atrapados en el sufrimiento y esperan una mano? ¿Cuántas enfermedades físicas, psicológicas y espirituales claman a gritos por ser curadas? ¿Cuánto bien podría hacer la teología si se entendiera a sí misma como medicina espiritual? El mundo del sufrimiento reclama a gritos el mundo de la medicina y del cuidado.

En las Homilías sobre el Cantar de los cantares, Gregorio interpreta a la Iglesia como esposa de Cristo que lo busca enamorada en medio de la noche, atraída por el olor de sus perfumes. En la catorceava homilía, hace una exégesis muy oportuna sobre el Buen Samaritano, que ciertamente ayuda a profundizar mejor en la invitación de Francisco a ser una Iglesia en salida. Gregorio subraya cinco elementos que se pueden formular como: primerear con misericordia haciéndose hermano, involucrarse cargando con todo lo humano, acompañar dando alivio en la propia posada, hacer fructificar los dos denarios que Cristo dejó en su Iglesia y que preparan y anticipan la celebración eterna en el cielo.

La exégesis se centra en el capítulo quinto del Cantar, en el cual, la esposa "enferma de amor" (Cant 5, 8) busca a su amado. Gregorio relaciona alegóricamente al esposo con el Buen Samaritano que toma la iniciativa y antes de que la esposa comience a buscarlo, se hace su hermano: "Éste es aquel a quien yo busco, se hizo nuestro hermano. Es descendiente de Judá, es el prójimo de aquel que fue asaltado por ladrones" (2015a: 181). Ciertamente, es indispensable primero tomar conciencia como Iglesia-esposa, "que el Señor tomó la iniciativa, la ha primereado en el amor (cf. 1 Jn 4,10); y, por eso, ella sabe adelantarse, tomar la iniciativa sin miedo, salir al encuentro, buscar a los lejanos y llegar a los cruces de los caminos para invitar a los excluidos" (Francisco, 2013b: 24).

Gregorio ve en el pasaje del Buen Samaritano, una bella síntesis de la historia de la salvación, "en una corta parábola, el Verbo le expone la benignísima misericordia de Dios contenida en la Escritura" (2015a: 181). Misericordia que se expresa, tanto para Francisco (2015c: n. 106; 2016) como para Gregorio (2012), en tender la mano para curar. Gregorio ve 
también en este gesto la actitud de Dios ante la historia, que lo lleva a abajarse como un médico $(2012$; 2015b) para levantar a la humanidad caída.

Jesús, el Buen Samaritano, primerea para involucrarse a fondo con entrañas de misericordia, sanando lo que "la insuficiencia de la Ley (no pudo), pues ni el sacerdote ni el levita curaron las heridas del hombre" (Gregorio, 2015a: 181). La Iglesia-esposa que sigue las huellas del esposo que se revistió de la naturaleza caída, "se mete con obras y gestos en la vida cotidiana de los demás, achica distancias, se abaja hasta la humillación si es necesario, y asume la vida humana, tocando la carne sufriente de Cristo en el pueblo" (Francisco, 2013b: n. 24). Gregorio resalta el gesto de cargar al herido en la propia cabalgadura (Lc 10, 34), como expresión de un compromiso a fondo, que recuerda al buen pastor que rescata a la oveja perdida y la carga "sobre su cuerpo ... llevó al hombre para curarle de sus miserias" (2015a: 181).

Francisco invita a una involucración que, a ejemplo del Buen Samaritano "acompaña a la humanidad en todos sus procesos, por más duros y prolongados que sean. Sabe de esperas largas y de aguante apostólico" (2013b: n. 24). Un acompañamiento que está representado para Gregorio, en el cuidado que el Samaritano le brinda al herido en la posada en la que lo acoge, recordando con ello que la Iglesia debe ser una comunidad de puertas abiertas, dispuesta a acoger la presencia de Cristo en todos cuantos sufren (2015a: 182).

Este acompañamiento "fiel al don del Señor también sabe fructificar ... porque el Señor la quiere fecunda" (Francisco, 2013b: n. 24). Para que el cuidado a los heridos sea fructífero, recuerda Gregorio que la Iglesia: "de él recibe dos denarios, uno de los cuales es amar a Dios con toda el alma y con el otro amar al prójimo como a sí mismo" (2015a: 182). Un fructificar que en Francisco, "celebra y festeja cada pequeña victoria, cada paso adelante" (2013b: n. 24) en los procesos curativos. Una celebración que se da en el horizonte litúrgico-sacramental, como un anticipo de la felicidad escatológica, que Gregorio relaciona con el final del pasaje del Buen Samaritano: "dice el Señor al hotelero que quien haya participado en los cuidados del herido, cuando él vuelva (juicio final), recibirá según hayan sido sus cuidados" (2015a: 182).

\section{CONCLUSIÓN}

En el presente trabajo, se ha hecho un recorrido por la medicina espiritual de Gregorio de Nisa, mostrando en varios de sus escritos, algunas sintonías con Francisco en su teología metafórica, experiencial, misericordiosa, mística, pedagógica, narrativa y comprometida con los pobres y los 
que más sufren. Ahora, se vuelve a la metáfora inicial, que sirvió de pretexto y punto de partida: la Iglesia en salida, como hospital de campo que necesita de un quehacer teológico que cure las heridas, desde "la misericordia (que) no es sólo una actitud pastoral, sino la sustancia misma del Evangelio de Jesús. Los animo a que estudien cómo, en las diferentes disciplinas ... se puede reflejar la centralidad de la misericordia" (Francisco, 2015a: n. 4).

No se espera que un teólogo cure las heridas físicas, pero si se espera que defienda la vida, que proteja a los menores, que luche por la igualdad de derechos y la dignidad del hombre y la mujer, que vele por las condiciones de vida de los pobres, que consuele a los tristes y que, finalmente, le dé sentido y orientación a una sociedad líquida, que ha perdido todo referente de orientación y significación. El cristianismo de hoy necesita de la santidad. Para ello, la metáfora propuesta por Francisco, se presenta como un modelo inspirador para suscitar hombres y mujeres que estén comprometidos con la realidad social y que sean médicos espirituales de cuantos sufren, desde la misericordia y la experiencia mística, que permite salir en éxtasis a amar a Cristo en los pobres. Como insiste el Niseno con su palabra y ejemplo, el teólogo está llamado a marcar "la gran diferencia que hay entre las palabras y la acción, como la diferencia entre una pintura y la realidad. El Señor afirma que seremos salvados, no por nuestras palabras sino por nuestras acciones" (2001: 203).

Con Gregorio, se puede entender mejor el pasaje del Buen Samaritano, el cual se debe leer dentro del sentido del capítulo 10 de Lucas, que termina con la actitud orante de María, que "escogió la mejor parte" (Lc 10,42) a los pies del maestro. La pregunta sobre ¿Qué debo hacer? (Lc 10, 25), se responde mejor desde la oración, porque como recuerda Francisco, "hay una sola forma de hacer teología: de rodillas. No es solamente un acto piadoso de oración para luego pensar la teología. Se trata de una realidad dinámica entre pensamiento y oración" (2015b), que se vuelca necesariamente en la salida misionera. De esta manera, la oración es fundamental en el quehacer teológico, porque es medicina, como lo recuerda el Niseno al contar el testimonio de la curación de una niña por intercesión de su hermana Macrina: "la verdadera medicina que cura las enfermedades y a la que ella se refería no es otra cosa que la medicina de la oración, que ya nos ha sido dada y ha actuado" (1995: 114).

Son muchas las heridas que la Iglesia debe salir a curar; son muchos los que se han alejado, por no ver sus propios pecados desde la medicina de la misericordia o por haber sido heridos por miembros de la misma comunidad eclesial. La Iglesia, para Francisco, tiene como primera misión "curar, curar las heridas, curar las almas, curar. Esta es vuestra primera misión, curar, curar a los heridos" (2017: 6). La razón de esta prioridad se 
encuentra en el sentido común, porque "cuando se va a un hospital de campaña, el primer trabajo es curar las heridas, no hacer el análisis del colesterol ... esto se hará después ... ¿Está claro?” (2014: 7).

A veces no parece tan claro y el sentido común se convierte en el menos común de los sentidos, cuando la teología se dedica a hacer discursos complejos que alienan la vida y poco tienen que decirles a los problemas concretos de las personas que mueren por falta de la medicina del Evangelio. En Gregorio, la teología parte de la contemplación y la acción, y tiende al mismo tiempo a ellas, en cuanto busca una unión cada vez más íntima con Dios, en consonancia con una vivencia más plena de la caridad evangélica.

Por otro lado, la imagen de la Iglesia como hospital es una invitación a curarse a sí misma de tantas tensiones, divisiones y dificultades que experimenta en el presente. Desde la curia romana hasta la parroquia rural más sencilla, la Iglesia necesita reformarse y ser hospital de campo, según esa bonita imagen que Nouwen retrató en el Sanador herido (2005). La Iglesia, como lo expresa Gaudium et Spes (1965), siente en su propio corazón las heridas de su tiempo, y las quiere asumir en espíritu de oración. Según Nouwen, estas heridas pueden ser el punto de partida de su propio servicio misionero, que constituye a la Iglesia en una servidora que cura desde sus heridas, porque "un conocimiento profundo de su dolor le permite convertir su debilidad en fuerza y ofrecer su propia experiencia como fuente de curación para los que, a menudo, están perdidos en la oscuridad de su propio sufrimiento incomprendido" (2005: 106).

La Iglesia, como hospital de campaña, es una unidad médica compuesta por sanadores heridos, que necesitan ser permanentemente curados por aquel que vino a curarlos con sus heridas (Is 53, 5). Los enfermos de este hospital han sido misericordiados y enviados por Cristo a ser curas de almas. Son médicos que están dispuestos a accidentarse, con tal de acompañar con constancia los procesos terapéuticos de sanación. No tienen miedo a arriesgarse con parresía (Francisco, 2018: n. 129-133), para vivir la santidad del Buen Samaritano, dejándose, al mismo tiempo, romper el corazón por el contacto con el que sufre. Al tocar la carne de Cristo en el prójimo, estos sanadores también reciben curación para sus heridas.

En la oración y el contacto con el que sufre, el teólogo es traspasado, como en el caso de Gregorio (2015a), por "el flechazo del amor" de Dios (160), en un éxtasis de amor, como más tarde lo desarrollará San Juan de la Cruz. Este flechazo hiere, pero, al mismo tiempo, cauteriza las otras heridas, propias y ajenas, que hay en el corazón. Desde el inicio de la vida, se producen continuas heridas en la mujer y el hombre, desde la separación del cordón umbilical y los primeros gemidos, hasta el atardecer de la vida en el que "te examinarán en el amor" (Juan de la Cruz, 2018). 
La medicina espiritual es mística, es un proceso de purificación que apunta hacia la unión del alma con Dios, en la que esta recobrará la salud y belleza original como Imago Dei. Según Danielou (1944), Gregorio es el "fundador de la teología mística" (7), por aportar un camino pedagógico de $\varepsilon \pi \varepsilon x \tau a \sigma \iota \varsigma$ para la medicina espiritual, un camino de configuración con Cristo que va del bautismo a la eucaristía (20-38). En el Niseno, la mística es seguir a Cristo "a donde quiera que El conduzca" (2015b: 252) y buscarlo en la oscuridad del momento presente, a menudo caracterizado por la pobreza y la injusticia. Es una mística, en que el alma debe pasar por los sufrimientos propios del crecer y del sanar las heridas:

Los que son tratados a base de sajaduras y de cauterios se irritan contra los que los curan, maltratados por el dolor del corte, pero, cuando, gracias a estos medios, se sigue la curación y el dolor del cauterio desaparece, no tienen más que gratitud para los que obraron sobre ellos la curación (Gregorio, 1990: 101-102).

Dios quiere prolongar sus manos curativas en los pequeños esfuerzos del quehacer teológico, porque es Cristo mismo quien se compadece de la humanidad, venda sus heridas con aceite y vino, la carga y la cuida en la Iglesia, a través de médicos espirituales que reciben de Él un encargo: "Cuida de él y, si gastas algo más, te lo pagaré cuando vuelva" (Lc 10, 35). La economía salvífica es medicinal, y así debe ser el quehacer teológico con los heridos en combate y con aquellos que se preparan para atenderlos, porque la labor profética de la teología ofrece una medicina preventiva para enfermedades más graves, que pueden llegar a ser mortales. La metáfora propuesta por Francisco, es una invitación a vivir una nueva ola de santidad en la Iglesia, como médicos enfermos, que, al amar, son sanados de la:

[...] enfermedad típica de la Iglesia encerrada ... autorreferencial ... encorvada sobre sí misma como aquella mujer del Evangelio ... una especie de narcisismo que nos conduce a la mundanidad espiritual y al clericalismo sofisticado (2013c: n. 3).

La Iglesia como hospital de campaña es un poderoso ícono que ilumina y atrae la mirada sobre el pobre y el que sufre; estos íconos vivos permiten "alcanzar una cura total ... al tocarlos" (Gregorio, 2001: 201). La Iglesia necesita ser sanada en el encuentro con la carne de Cristo, en los no nacidos, los pobres, las víctimas de la violencia y en tantos rostros que se encuentran a diario en las calles, como lo sigue anunciando Gregorio: 
Una multitud de prisioneros de guerra llama a las puertas de cada uno de nosotros ... Abraza al desgraciado como si fuese oro. Pon tanto cuidado en la salud del pobre enfermo, como si se tratase de la tuya... Porque si hemos de ayudar y dar apoyo a todos los pobres, sobre todo nos hemos de preocupar por los enfermos. Porque quien al mismo tiempo es pobre y enfermo, sufre con doble pobreza (1988: 67).

\section{REFERENCIAS}

Aristóteles. (2012). Ética Nicomaquea (Tercera edición). (Antonio Gómez, Trad.) México: Universidad nacional autónoma de México.

Berzosa, R. (1994). Hacer teología hoy. Retos, perspectivas, paradigmas. Madrid: San Pablo.

Brighenti, A. (2015). Perfil de la Iglesia que sueña el Papa Francisco. En J. M de Silva (Ed.), Papa Francisco. Perspectivas y expectativas de un papado (pp. 1939). Madrid: Herder.

Brouchet, J. R. (1968). La vision de l'economie du salut selon S. Grégoire de Nysse. Revue des Sciences Philosophiques et Théologiques, 70(4), 613-644.

Celam. (2007). V Conferencia general del episcopado latinoamericano, Aparecida. Bogotá: Centro de publicaciones del Celam.

Coda, P. (2017). La Chiesa è il Vangelo. Alle sorgenti della teologia di papa Francesco. Roma: Editrice Vaticana.

Comisión Teológica Internacional. (2011). La teología hoy: perspectivas, principios y criterios. Disponible en http://www.vatican.va/roman_curia/congregations/cfaith/cti_documents /rc_cti_doc_20111129_teologia-oggi_shtml\#NOTA_PRELIMINAR

Concilio Vaticano II. (1965). Constitución Apostólica Gaudium et Spes. En Concilio V aticano II. Documentos completos (Ed. 2000). Bogotá: San Pablo.

Congregazione per l'educazione cattolica. (1989). Istruzione sullo studio dei Padri della Chiesa nella formazione sacerdotale. Disponible en http://www.vatican.va/roman_curia/ congregations/ccatheduc/documents/rc_con_ccatheduc_doc_1989111 0_padri_it.html

Danielou, J. (1944). Platonisme y Théologie Mystique. Paris: Aubier.

Drobner, H. R. (2006). Alegoría. En Mateo Seco, L. \& Maspero, G. (Eds.), Diccionario de San Gregorio de Nisa. (pp. 189-208). Burgos: Monte Carmelo.

Fernández, S. (1999). Cristo médico, según Orígenes, la actividad médica como metáfora de la acción divina. Roma: Institutum Patristicum Agustinianum.

Francisco. (2013a). Vigilia de pentecostés con los movimientos eclesiales. Disponible en http://w2.vatican.va/content/francesco/es/speeches/2013/may/documents/papa-francesco_20130518_veglia-pentecoste.html 
Francisco. (2013b). Exhortación apostólica Evangelii gaudium. Disponible en http://w2.vatican.va/content/francesco/es/apost_exhortations/documents/papa-francesco_esortazione-ap_20131124_evangelii-gaudium.html

Francisco. (2013c). Carta del Papa Francisco a la $105^{\circ}$ Asamblea Plenaria de la Conferencia Episcopal Argentina. Disponible en https://w2.vatican.va/content/francesco/ es/letters/2013/documents/papa-francesco_20130325_lettera-vescovi-argentina.html

Francisco. (2013d). Entrevista al Papa Francisco, Antonio Spadaro. Disponible en https://w2.vatican.va/content/francesco/es/letters/2013/documents/papa-francesco_20130325_lettera-vescovi-argentina.html

Francisco. (2014). Discurso del Santo Padre a los participantes en la asamblea general del movimiento de los Focolares. Disponible en http://w2.vatican.va/content/francesco/es/speeches /2014/september/documents/papa-francesco_20140926_movimento-focolari.pdf

Francisco. (2015a). Carta del santo padre Francisco al gran canciller de la Pontificia Universidad Católica Argentina en el centenario de la Facultad de Teología. Disponible en http://w2.vatican.va/content/francesco/es/letters/2015/documents/papa-francesco_20150303_lettera-universita-cattolica-argentina.html

Francisco. (2015b). Videomensaje del santo padre Francisco al Congreso Internacional de Teología organizado por la Pontificia Universidad Católica Argentina. Disponible en https://w2.vatican.va/content/francesco/es/messages/pontmessages/2015/documents/papa-francesco_20150903_videomessaggio-teologia-buenos-aires.html

Francisco. (2015c) Laudato si'. Disponible en http://w2.vatican.va/content/francesco /es/encyclicals/documents/papa-francesco_20150524_enciclica-laudato-si.html

Francisco. (2016). Discurso a una representación de médicos españoles y latinoamericanos. Disponible en https://w2.vatican.va/content/ francesco/es/speeches/2016/june/ documents/papa-francesco_20160609_ordini-medici-spagna-america-latina.html

Francisco. (2017). Encuentro con los obispos de Myanmar. Disponible en https://w2.vatican.va/content/francesco/es/speeches/2017/november/documents/papa-francesco_20171129_viaggioapostolico-myanmar-vescovi.html

Francisco. (2018). Exhortación apostólica Gaudete et Exsultate. Disponible en http://w2.vatican.va/content/francesco/es/apost_exhortations/documents/papa-francesco_esortazione-ap_20180319_gaudete-et-exsultate.html\#Audacia_y_fervor

Galli, C. (2017) ¿Una nueva fase en la teología ibero-americana? ¿Un salto hacia el futuro de la teología en castellano? Teología, 54(122), 131-162.

Garavito, D. (2017). Hermenéutica de la acción. Apropiación para una teología de la acción humana. En Martínez, D. (Dir.) El arte de interpretar en teología. Compendio de hermenéutica teológica (pp. 279-298). Bogotá: Universidad Javeriana. 
González, C. I. (1988). Pobreza y riqueza en obras selectas del cristianismo primitivo. México: Porrúa.

Gregorio de Nisa. (1983). La preghiera del signore. (Caldarelli, G., Trad.) Roma: Edizioni Paoline.

Gregorio de Nisa. (1988). Homilía contra los prestamistas usureros. En González C. (Trad.), Pobreza y riqueza en obras selectas del cristianismo primitivo. (pp. 65-93). México: Porrúa.

Gregorio de Nisa. (1990). La gran catequesis. (Velasco, A., Trad.) Madrid: Ciudad Nueva.

Gregorio de Nisa. (1995). Vida de Macrina, Elogio de Basilio. (Mateo-Seco, L., Trad.) Madrid: Ciudad Nueva.

Gregorio de Nisa. (2000). De virginitate. (Mateo-Seco, L., Trad.). Madrid: Ciudad Nueva.

Gregorio de Nisa. (2001). On the love of the poor: 2. On the saying, Whoever has done it to one of these has done it to me. En Holman S. (Trad.), The bungry are dying (pp. 199-206). New York: Oxford University Press.

Gregorio de Nisa. (2012). Homilías sobre el Eclesiastés. (Cornavaca, R. \& Peveraro, O. Trads.). Madrid: Ciudad nueva.

Gregorio de Nisa. (2014a). L'anima e la resurrezione. En C. Moreschini (Ed. y trad.) Gregorio di Nissa, opere dogmatiche (pp. 681-1726). Milán: Bompiani.

Gregorio de Nisa. (2014b). Contra Eunomio. En C. Moreschini (Ed. y trad.) Gregorio di Nissa, opere dogmatiche (pp. 681-1726). Milán: Bompiani.

Gregorio de Nisa. (2015a). Homilías sobre el Cantar de los Cantares (Ed. 2001). En Semillas de contemplación (Martín, T., Trad., pp. 5-196). Madrid: Biblioteca de Autores Cristianos.

Gregorio de Nisa. (2015b). Vida de Moisés (Ed. 2001). En Semillas de contemplación (Martín, T., Trad., pp. 197-336). Madrid: Biblioteca de Autores Cristianos.

Gregorio de Nisa. (2016). On the making of man (Ed. 1892). (Schaff, P., Trad.) New York: Aeterna Press.

Gregorio Taumaturgo. (1994). Elogio del maestro cristiano (Segunda edición). (Merino, M., Trad.). Madrid: Ciudad Nueva.

Gutiérrez, G. (1995). Hablar de Dios desde el sufrimiento del inocente. Una reflexión sobre el libro de Job (Tercera edición). Salamanca: Ediciones Sígueme.

Holman, S. (2001). The bungry are dying. New York: Oxford University Press.

Jaeger, W. (2001). Paideia, los ideales de la cultura griega (Decimoquinta reimpresión). (Xiral, J., Trad.) México: Fondo de Cultura Económica.

Janini, J. (1946). La antropología y la medicina pastoral en Gregorio de Nisa. Madrid: Consejo superior de investigaciones científicas.

Juan de la Cruz. (2018). Dichos de amor y luz. Disponible en http://www.sanjuandelacruz.com/dichos-de-amor-y-de-luz/

Juan Pablo II. (1980). Carta apostólica Patres Ecclesiae, con ocasión del XVI centenario de la muerte de San Basilio. Disponible en https://w2.vatican.va/content/john-paul-ii/es/apost_letters/1980/documents/hf_jpii_apl_02011980_patres-ecclesiae.html 
Kavanagh, J. (2014). La teología del papa Francisco. Telos, (1), 5-12.

Larchet, J.C. (2014). Terapéutica de las enfermedades espirituales (M. H. Luxán, Trad.). Salamanca: Sígueme.

Lonergan, B. et al. (1972). Teología de la renovación (T. 1 y 2. Donaire, M; Álvarez, J.; González, M. y Martínez, J., Trads.). Salamanca: Sígueme.

Maraval: (2006). Biografía de Gregorio de Nisa. En Mateo-Seco, L. \& Maspero, G. (Eds.), Diccionario de San Gregorio de Nisa (pp. 189-208). Burgos: Monte Carmelo.

Mateo-Seco, L. (2006). Teología espiritual. En Mateo-Seco, L. \& Maspero, G. (Eds.), Diccionario de San Gregorio de Nisa (pp. 843-853). Burgos: Monte Carmelo.

Mikoski, G.S. (2006). Baptism, Trinity, and ecclesial pedagogy in the thought of Gregory of Nyssa. Scottish Journal of Theology, 59(2), 175-182.

Monge, M. A. (2003). Medicina pastoral, cuestiones de biología, antropología, medicina, sexología, psicología y psiquiatría (Tercera edición). Madrid: Eunsa.

Moreschini, C. (2014). Gregorio di Nissa, opere dogmatiche. Milán: Bompiani.

Niedermeyer, A. (1955). Compendio de medicina pastoral (Ed. 1953). (Rodrigo, I., Trad.) Barcelona: Herder.

Nouwen, H. (2005). El sanador herido (Ed. 1971). (Ortega, E., Trad.) Barcelona: PPC Altres.

Orígenes. (1969). Lettre D’Origène a Grégoire Le Taumaturge. En Crouzel, H. (Ed.), Remerciement a Origène, lettre D’Origène a Grégoire (pp. 187-195). París: Editions du Cerf.

Pablo VI. (1965). Address of pope Paul VI during the last general meeting of the Second Vatican Council. Disponible en https://w2.vatican.va/content/paulvi/en/speeches/1965/ documents/hf_p-vi_spe_19651207_epilogo-concilio.html

Platón (2014). Apología de Sócrates (Octava edición). (Vigo, A. Trad.) Santiago: Editorial Universitaria.

Quasten, J. (1977). Patrología (Tercera edición). (Oñatibia, I., Trad; Vol. II) Madrid: Biblioteca de Autores Cristianos.

Ricouer, P. (2002). Del texto a la acción. Ensayos de hermenéutica II (Segunda edición). (Corona, P., Trad.) México: fondo de cultura económica, 2002.

Rupnik, M. (2017). Secondo lo Spirito. La teologia spirituale in camino con la Chiesa di papa Franceso. Roma: Editrice Vaticana.

Saranyana, J. (2005). Cien años de Teología en América Latina (1899-2001) (Ed. 2005). Bogotá: CELAM.

Silvas, A. (2007). Gregory of Nyssa: The letters. Leyden, Holanda: Brill.

Solano, O. (2015). Inculturación de la teología en Gregorio Nisa: antecedentes. Theologica Xaveriana, 65(179), 157-183.

Solano, O. (2018). La espiritualidad como crecimiento constante. Aporte de Gregorio de Nisa. Perseitas, 6(1), 48-70.

Spadaro, A. \& Galli, C. (2016). La reforma y las reformas de la Iglesia. (Spadaro, A. \& Galli, C., Eds.) Santander: Sal Terrae. 
Tamayo, J. C. (2003). Nuevo paradigma teológico. (Segunda edición). Madrid: Trotta.

Sumario: Introducción; 1. La reforma de la Iglesia en salía; 2. San Gregorio de Nisa y la medicina; 2.1. Contextualización biográfica; 2.2. El estilo de hacer teología; 2.3. El rol de la medicina en su vida y sus escritos; 3. La medicina espiritual en Gregorio de Nisa; 3.1. Cristo médico; 3.2. El quehacer teológico como medicina espiritual; 3.3. La medicina espiritual como pedagogía; 3.4. La medicina de la misericordia; 3.5. Al estilo del Buen Samaritano; Conclusión; Referencias. 